\title{
EDITORIAL
}

\section{Legal Aspects of Corporate Social Responsibility}

\author{
Tineke Lambooy* \\ * Molengraaff Institute for Private Law and the Research Institute of Water, Oceans and Sustainability Law, \\ Utrecht University, the Netherlands \\ t.e.lambooy@uu.nl
}

Keywords: CSR; Corporate Social Responsibility; Earth Charter; UN Guiding Principles; OECD Guidelines for Multinational Enterprises; National Contact Points; state liability for climate change; corruption; private regulation

\begin{abstract}
We stand at a critical moment in Earth's history, a time when humanity must choose its future. As the world becomes increasingly interdependent and fragile, the future at once holds great peril and great promise. To move forward we must recognize that in the midst of a magnificent diversity of cultures and life forms we are one human family and one Earth community with a common destiny.

Preamble of the Earth Charter ${ }^{1}$
\end{abstract}

Indeed, the world is becoming increasingly interdependent and fragile due to a growing population searching for more material wealth, the scarcity of resources, the loss of biodiversity and ecosystems, climate change, shifts in power between States and also between States and multinational companies, wars and international peace processes. Multinational enterprises (MNEs) are playing an ever increasing role in this arena: applying environmental care (or not), producing and selling arms (or not), paying a decent salary to their employees (or not), offering remedies to victims of human rights abuses and environmental pollution (or not), paying bribes to judges and other people in power (or not), lobbying for or against legal measures to reduce greenhouse gases emissions (GHG), sponsoring political campaigns, and so forth.

Corporate Social Responsibility (CSR) has become a well known concept over the last decade and a half. ${ }^{2}$ Employees, government representatives, academic scholars, NGOs and international organisations have been contemplating which role they have to play in regard of CSR. Laws have been drafted that promote socially responsible behaviour by companies. ${ }^{3}$ International organisations have promoted principles. Companies have adopted CSR mission statements and programmes, and are sharing their efforts through sustainability reports. NGOs have contacted companies and pointed out how they can operate in a more responsible way, and academics have analysed all.

CSR is a subject that has links with many areas of law, including international law and European law, corporate law and corporate governance, tort law and contract law, procedural law, labour and environmental law, and criminal law. All of these areas contribute importantly to the development of CSR, and ultimately to respond to the serious challenges that this world faces. This special issue of the Journal of International and European Law covers various of these areas and offers interesting insights in the developing course of the legal aspects of CSR.

In view of the global challenges, international (and European) law is particularly indispensable. It is the backbone of the vision as stated by the Earth Charter quoted above that "we must recognize that ... we are one Earth community with a common destiny.' The Earth Charter is a modern declaration of fundamental ethical principles for building a just, sustainable and peaceful global society in the 21st Century. It includes in short form all principal values covered by among other the Universal Declaration of Human Rights, international human rights and environmental treaties. ${ }^{4}$ This document is the result of a decade-long, worldwide,

\footnotetext{
${ }^{1}$ Earth Charter <http://www.earthcharterinaction.org/content/pages/Read-the-Charter.html>.

2 Tineke Lambooy, Corporate Social Responsibility. Legal and semi-legal frameworks supporting CSR (Kluwer 2010), <https://openaccess.leidenuniv.nl/handle/1887/16169>.

3 Indonesian Corporate Law and Investment Law oblige CSR. See Tineke Lambooy and others, CSR in Indonesia: legislative developments and case studies (Konstitusi Press 2013).

4 Ruud Lubbers and Willem van Genugten and Tineke Lambooy, Inspiration for Global Governance (Kluwer 2008).
} 
cross-cultural dialogue on common goals and shared values. ${ }^{5}$ As a non-legal instrument developed by worldwide civil society, the Earth Charter is utilised by, and supports the efforts of, NGOs, companies, and governments in various parts of the world. It has been adopted as a mission statement by private as well as public organisations, and it is used externally to explain the organisation's values in communication with stakeholders. CSR flourishes when people who have to implement it understand the bigger picture. As the Preamble of the Earth Charter states:

'we must decide to live with a sense of universal responsibility, identifying ourselves with the whole Earth community as well as our local communities. We are at once citizens of different nations and of one world in which the local and global are linked. Everyone shares responsibility for the present and future well-being of the human family and the larger living world.'

The Earth Charter may serve the purpose of assisting people in understanding their own responsibility. Below, just for illustrative purposes, I will refer to some of its provisions, but only after I have highlighted the interesting legal aspects presented in the contributions included in this issue of the Journal of International and European Law with the title 'Legal Aspects of Corporate Social Responsibility'. Nonetheless, as the articles in this Journal will demonstrate, private regulatory regimes, quasi-legal rules and soft law also play an important role in the process of implementation of CSR by companies as well as in the evolution of traditional legal regimes.

Justine Nolan ('Refining the Rules of the Game: The Corporate Responsibility to Respect Human Rights') investigates in her article the interplay between on the one hand legal norms for companies to avoid (complicity to) human rights violations and, on the other hand, quasi-legal norms and programmes that assist companies in achieving such goal. She applauds the steady evolution of a global social expectation that companies should respect international human rights standards, ${ }^{7}$ but she finds fault at the side of governments which do not enforce legislation concerning for instance employment safety norms. She exposes that after the collapse of the Rana Plaza in Dhaka, Bangladesh (2013), causing the death of 1,100 textile workers, the global press primarily focussed on the role of global companies in preventing and remedying the problem of workers' safety in Bangladeshi supply chain companies. Nolan explains that subsequently various non-legal initiatives evolved which recognised 'the limited governmental capacity to provide a short-term remedy to prevent further disasters and accept[ing] that corporate social responsibilities extend beyond those that can be defined in stark legal terms.' These multi-stakeholder initiatives adopted collective workplace safety standards and auditing plans. Nolan indicates that such initiatives are helpful to fill in the gap of local public enforcement of labour laws. Additionally, she adds that legal mechanisms imposed on companies can effectively complement the non-legal approach. She points at the initiative of some States to legislate extraterritorially that companies create transparency about their human rights impact. ${ }^{8}$ Her views have a similar approach as the Earth Charter which also advises that a multiplicity of stakeholders must work together in order 'to bring forth a sustainable global society founded on respect for nature and universal human rights...' (Preamble Earth Charter). ${ }^{9}$

In the article, 'Jurisdiction by Necessity and the Regulation of the Transnational Corporate Actor', Chilenye Nwapi provides a technical analysis of the arguments which national courts (can) use to accept or reject jurisdiction in respect of human and environmental rights claims filed by victims against multinational

\footnotetext{
${ }^{5}$ The 'Earth Charter project' began as a United Nations (UN) initiative, but it was carried forward and launched as a global civil society initiative in 2000 by the Earth Charter Commission, an independent international entity. The drafting of the Earth Charter involved the most inclusive and participatory process ever associated with the creation of an international declaration. This process is the primary source of its legitimacy as a guiding ethical framework. The legitimacy of the document has been further enhanced by its endorsement by over 4,500 organisations, including many governments and international organizations. http://www.earthcharterinaction.org/content/pages/What-is-the-Earth-Charter\%3F.html.

6 Earth Charter (n 1).

7 Also confirmed by the UN Human Rights Council; see 'Guiding Principles on Business and Human Rights: Implementing the United Nations 'Protect, Respect and Remedy' Framework: Report of the Special Representative of the Secretary-General on the issue of Human Rights and Transnational Corporations and Other Business Enterprises', A/HRC/17/31 (21 March 2011) (UN Guiding Principles).

8 She refers to the Sections 1502 and 1504 of the US Dodd-Frank Act, the Burma Responsible Investment Reporting Requirements (http://www.humanrights.gov/wp-content/uploads/2013/05/Responsible-Investment-Reporting-Requirements-Final.pdf), and the 2013 EU Accounting and Transparency Directives.

9 Earth Charter (n 1).
} 
corporations. He examines the options to apply the 'forum necessitatis' doctrine (jurisdiction by necessity doctrine) aimed at offering access to justice to victims. Nwapi argues that 'the nature and reach of the operations of TNCs [transnational corporations] have rendered them almost impervious to traditional standards of jurisdiction'. He explains that if a violation takes place in another location than in the MNE's Home State, the court in the Home State may lack the territorial jurisdiction to adjudicate a dispute. However, the forum necessitatis theory allows such Home State court to take up the case if there is - in technical or practical terms $^{10}$ - no other forum in which the victim can initiate the suit. As Nwapi puts it: 'The dominant concern is therefore the need to avoid a denial of access to justice $-\mathrm{a}$ fundamental objective of modern international law. ${ }^{11}$ I refer to the Earth Charter which also promotes to 'Recognize the ignored, protect the vulnerable, serve those who suffer, ... (9.d) and to "Require multinational corporations and international financial organizations to act transparently in the public good, and hold them accountable for the consequences of their activities (10.d). ${ }^{12}$ The jurisdiction by necessity regime can support the realisation of these goals.

In the context of CSR, as has also been mentioned by Nolan, a large variety of private self-regulatory instruments related to social or environmental aspects of economic activities, such as codes of conduct or private labels, have emerged. ${ }^{13}$ Some have been adopted unilaterally by multinational companies, others have been developed together with NGOs or international institutions. ${ }^{14}$ These instruments often have acquired legal effect under private law because they have become part of supply chain contracts and under labour law if they have been referred to in labour agreements. Carola Glinski ('Competing Transnational Regimes under WTO Law') argues that such private regulatory instruments can also acquire legal effect in public international law when they would qualify as 'international standards' under World Trade Organisation (WTO) law. She explains that the concept of 'international standards' in the WTO Agreement on Technical Barriers to Trade (TBT Agreement) plays an important role: '[S]tates are required to base their technical (e.g. environmental) regulations on international standards and are provided a justification for their technical regulations that are in accordance with these standards'. The references to 'international standards' ${ }^{\prime 15}$ can be regarded as 'collision norms', according to Glinsky. When public and private norms compete, the most legitimate public or private standard for governing the problem at hand should be chosen. Depending on the situation, a private standard or label could be more legitimate with regard to the interests concerned than a public norm. Factors that constitute legitimacy are for example the level of participation of relevant stakeholders in the drafting of the norm and whether the decision-making process can be considered a democratic process; the type of the public interest at stake also plays a role. ${ }^{16}$ The argument put forward by Glinsky is reminiscent to the Earth Charter's provisions alluding to democracy, e.g. the provision to 'Strengthen democratic institutions at all levels, ... , inclusive participation in decision making ... ' (13)..$^{17}$

Scott Robinson addresses a very topical issue in the CSR discourse: 'International Obligations, State Responsibility, and Judicial Review Under the OECD Guidelines for Multinational Enterprises Regime' (the OECD Guidelines). The subject of his research regards the OECD Guidelines and the regime of so-called 'National Contact Points' (NCPs). ${ }^{18}$ Each of the OECD Member States must set up a NCP within its domestic system. This NCP is to be responsible for promoting the MNE Guidelines and to resolve issues that arise under the OECD Guidelines. Stakeholders can submit complaints about violations of the OECD Guidelines by companies with the NCP in their State. A NCP is considered a state-based non-judicial grievance mechanisms'. ${ }^{19}$ NCPs in different States are to cooperate on matters and report regularly. Robinson analyses what the legal nature under international law is of the State's responsibility to establish a NCP. He reasons that it concerns a State obligation. Subsequently, he refers to various reviews by the NGO OECD Watch of the functioning of NCPs and concludes that this has not been a success story. ${ }^{20}$ Robinson argues that the nature

\footnotetext{
${ }^{10}$ This concerns especially countries with weak accountability mechanisms.

${ }^{11}$ Nwapi refers to article 6(1) of the European Convention on Human Rights.

${ }_{12}$ Earth Charter (n 1).

${ }^{13}$ Lambooy (n 2) ch 6 'Private regulation: setting the standards', 227-276.

14 ibid 230-231.

${ }^{15}$ Ie in Articles 2.4 and 2.5 TBT Agreement.

${ }^{16}$ Lambooy (n 13) 256-260.

${ }^{17}$ Earth Charter (n 1).

18 OECD, OECD Guidelines for Multinational Enterprises, 2011 Edition; http://www.oecd.org/daf/inv/mne/48004323.pdf.

${ }^{19}$ UN Guiding Principles (n 7).

${ }^{20}$ Eg OECD Watch, The OECD Guidelines for MNEs: Are they fit for the job'?(2009), 5-6 <http://oecdwatch.org/publications-en/Publication_3201/> [Fit for the job?]. Robinson mentions problems such as: there exists no uniform structure for NCPs; most NCPs lack
} 
of the obligation of the OECD Member States to implement a NCP is relevant now that the question has emerged how this obligation can be enforced. He asserts that no review mechanism exists, neither domestically nor internationally. The point that Robinson makes is that States should institute effective and efficient access to administrative and independent judicial and non-judicial procedures, including remedies and redress for environmental and human rights harm, also when this has been caused by companies (the Earth Charter urges this in provision 13.d). ${ }^{21}$

In his article 'Kiobel, Corporations, the ATS \& American Exceptionalism', Benjamin Thompson analyses a widely discussed US Supreme Court case..$^{22}$ He considers the Kiobel case against the backdrop of the functioning of the US Alien Tort Statute (ATS). The decision applied the presumption against extraterritoriality to the ATS. Thompsom evaluates the decision using the criteria of leading scholars in their discussions regarding American exceptionalism. He comes to the conclusion that ATS litigation in principle has the potential to provide accountability in situations where MNEs commit serious human rights violations. However, the ATS should not be regarded as a statute that enforces international law. Moreover, Thompson asserts that no binding international law exists in respect of human rights violations committed by companies. He poses the question 'whether litigation under the ATS can be justified under the moral need for such accountability'.

Jeffrey A. Van Detta presents an interesting essay on 'Sexual Orientation, Human Rights, and Corporate Sponsorship of the Sochi Olympic Games: Rethinking the Voluntary Approach to Corporate Social Responsibility'. He questions the sponsorship of the Sochi Winter Olympic Games by the European MNE Atos S.E., because he sees this as aiding and abetting a Host State government that has recently enacted harsh legislation aimed at the Lesbian, Gay, Bisexual, Transgender, and Intersex (LGBTI) communities within Russia. Van Detta argues that if CSR has to mean anything, European MNEs have to fully support Europe's commitment to human rights in general, and to the human rights of LGBTI individuals in particular, because they are among EU citizens and the citizens of the world who are still being undermined and dishonoured. Van Detta offers a working definition for CSR which insists on going beyond the minimal in protecting and promoting human rights. He proposes an approach to employing disclosures in regulating CSR to promote human rights. His proposal is based on Section 116 of France's Nouvelles Régulations Économiques and California's Transparency In Supply Chains Act of 2010. In this context, I refer to the Earth Charter's provision 12.a which like Van Detta also emphasises that discrimination in all its forms, such as that based on race, color, sex, sexual orientation, religion, language, and national, ethnic or social origin, should be eliminated, and that each organisation has a vital role to play ('The way forward') and to provision 10.d. that requires that MNEs 'act transparently in the public good'. ${ }^{23}$

The case note by Roger Cox ('Urgenda') is particularly interesting for those of us who are concerned about climate change. Whereas scientific findings indicate that worldwide emissions of greenhouse gases (GHG) must be cut down drastically if we are to prevent dangerous climate change, still, legislators and companies are not forthcoming in taking actions capable of producing the drastic reductions needed. Cox underlines that many States have assumed legal obligations to reduce $\mathrm{GHG}^{24}$ The question posed in his case note is whether an individual European State could be held liable for not properly responding to this global issue?

involvement from other stakeholders, such as NGOs, and lack an oversight body; the handling of specific instances is particularly problematic; the NCP complaints procedures vary from NCP to NCP and it is unclear how NCPs handle parallel proceedings (i.e. across several NCPs); NCPs have weak investigatory powers; there are complaints about inequitable treatment of parties; inconsistencies have been noted in interpreting the scope of the MNE Guidelines across different NCPs; outright rejection of specific complaints and the erroneous reasons for doing so present a major dilemma within the NCP system; and there is the question of transparency in the process.

${ }^{21}$ Earth Charter (n 1).

22 Kiobel v. Royal Dutch Petroleum Co, 133 S Ct 1659 (2013).

${ }^{23}$ Earth Charter (n 1$)$.

${ }^{24}$ Cox: 'For industrialised nations like the Netherlands and other European countries, rates within the $25-40 \%$ range have been established by the international community of government representatives under the 1992 UN Climate Convention, as the scale of reduction required by 2020 on the basis of climate science to secure any reasonable chance of preventing 'dangerous climate change'. 195 countries (including the EU and its Member States) are a party to this Convention and to the Cancun Agreements of 2010, in which the signatory countries explicitly acknowledge that an average temperature increase of more than 2 degrees Celsius qualifies as 'dangerous anthropogenic interference' as referred to in the 1992 UN Climate Convention. In the Cancun Agreements, it is also acknowledged that 'such an increase is a threat to humanity and could lead to the infringement of human rights in all countries and all regions of the world.' 
On November 20, 2013 the Dutch NGO Urgenda ${ }^{25}$ and 886 individual citizens served summons on the Dutch State in an action to hold the Netherlands liable for its role in causing dangerous global climate change. The goal of the action is to obtain an order obliging the Dutch State to take measures to reduce GHG emissions before 2020. Cox is legal counsel to the plaintiffs. In this case note, he presents the arguments invoked against the Dutch State. In particular, the tort of negligence and the duty of care as well as the principle of several or proportionate liability, both as applied in Dutch law, are elaborated on. Cox contends that other European countries employ similar approaches ${ }^{26}$ and that Urgenda's claims could also be installed against other European States. About the link between climate change and human rights, Cox asserts: 'According to the UN Human Rights Council (Resolution 10/4 of 2009), the danger with climate change, and especially a climatic change of more than 2 degrees, poses a threat to human rights around the world, most notably to the right to life and the right to health. Heat stress, floods, sea level rises, the spread of infectious diseases, summer smog, the degradation and loss of ecosystems and flora and fauna and the risks to drinking water and food supplies will contribute to mounting violations, both in the Netherlands, Europe and around the world, of the right to life (Article 2 of the European Convention of Human Rights; ECHR) and the right to health and respect for private and family life (Article 8 of the ECHR).' The initiative of the Urgenda court case addresses the Earth Charter's concerns to 'Protect and restore the integrity of Earth's ecological systems' (5). ${ }^{27}$ What Urgenda does is indeed to 'Take action to avoid the possibility of serious or irreversible environmental harm even when scientific knowledge is incomplete or inconclusive' as promoted by the Earth Charter (6.a). ${ }^{28}$

Rhuks Ako reviews the book 'Corporate Social Responsibility of Multinational Corporations in Developing Countries: Perspectives on Anti-Corruption' by Adefolake O. Adeyeye. He describes that in the book the author takes a stand that a CSR approach should be adopted to curb the involvement of multinational companies in corrupt practices, particularly in developing countries. Corruption is considered a CSR issue which should be regulated in an effective manner. The Earth Charter also promotes a corruption-free society: 'Eliminate corruption in all public and private institutions' (13.d). ${ }^{29}$

And lastly, this Journal ends with an interesting interview with Ursula Wynhoven who is the General Council of the UN Global Compact, which is one of the most widely known private regulatory regimes concerning CSR. ${ }^{30}$ I note that in 2008 the Earth Charter Initiative and the Global Compact entered into a cooperation. $^{31}$

${ }^{25}$ Stichting Urgenda is a foundation established on January 17, 2008 with the (statutory) aim of advancing and accelerating the processes needed for a transition to a sustainable society, focusing first on the Netherlands.

${ }^{26}$ Cox refers to Cees van Dam, European Tort Law (OUP 2013), 1108-1; AJ Akkermans, 'Veroorzaking van deelschade' (1992) 6043 Weekblad voor privaatrecht, notariaat en registratie 250; and the European Group of Tort Law, Principles of European Tort Law, Text and Commentary (Springer 2005), ch 3 'Causation, articles 3:102-3:106' and ch 4 'Liability Based on Fault, article 4:102'.

27 Earth Charter (n 1).

${ }^{28}$ Earth Charter (n 1). The Earth Charter also emphasises to: 'Ensure that decision making addresses the cumulative, long-term, indirect, long distance, and global consequences of human activities' (6.c) and to 'Act with restraint and efficiency when using energy, and rely increasingly on renewable energy sources such as solar and wind (7.b).

${ }^{29}$ Earth Charter (n 1).

${ }^{30}$ Global Compact; http://www.unglobalcompact.org/.

31 See The Earth Charter, GRI and The Global Compact (2008), which paper provides an assessment of the main similarities and dif ferences between the Earth Charter, the Global Compact and the GRI; and it provides practical advice on how Earth Charter users might use these other initiatives to implement the Charter, and vice versa; $<$ http://www.earthcharterinaction.org/invent/details. php?id=683 $>$ and $<$ http://www.earthcharterinaction.org/content/categories/Business/>. 


\section{Bibliography}

Akkermans AJ, 'Veroorzaking van deelschade' (1992) 6043 Weekblad voor privaatrecht, notariaat en registratie 250

European Group of Tort Law, Principles of European Tort Law, Text and Commentary (Springer 2005)

Lambooy TE, Corporate Social Responsibility. Legal and semi-legal frameworks supporting CSR (Kluwer 2010), $794<$ https://openaccess.leidenuniv.nl/handle/1887/16169>

Lambooy TE and others, CSR in Indonesia: legislative developments and case studies (Konstitusi Press 2013) Lubbers R and Van Genugten W and Lambooy TE, Inspiration for Global Governance (Kluwer 2008)

OECD Watch, The OECD Guidelines for MNEs: Are they 'fit for the job'? (2009)

Van Dam C, European Tort Law (OUP 2013)

How to cite this article: Tineke Lambooy, 'Legal Aspects of Corporate Social Responsibility' (2014) 30(78) Utrecht Journal of International and European Law 1, DOI: http://dx.doi.org/10.5334/ujiel.bz

Published: 28 February 2014

Copyright: (c) 2014 The Author(s). This is an open-access article distributed under the terms of the Creative Commons Attribution 3.0 Unported License (CC-BY 3.0), which permits unrestricted use, distribution, and reproduction in any medium, provided the original author and source are credited. See http://creativecommons.org/ licenses/by/3.0/.

] $\mathbf{u}$ [ Utrecht Journal of International and European Law is a peer-reviewed open access journal published by Ubiquity Press. 